\title{
Forum
}

\section{Quantitative vs. Qualitative Research in Transformation Process}

(Questions to the Experts)

1. How would you characterize yourself and your approach?

2. What are, in your opinion, the major fields in current transformation research in East Europe?

3. What do you think to be the gravest substantial deficits in these fields?

4. Which methodological deficits are most important for you?

5. How do you view the research potential in East Europe in these fields?

6. Please sketch a design for transformation research which could be appropriate for the current situation!

\section{Quantitative vs. Qualitative Ansätze in der Transformationsforschung}

(Fragen an die Experten)

1. Wie würden Sie sich und Ihren Forschungsansatz charakterisieren?

2. Wo sehen Sie gegenwärtig die Schwerpunkte in der Transformationsforschung in Osteuropa?

3. Welches sind Ihrer Meinung nach zur Zeit die gravierendsten Defizite inhaltlicher Art in diesem Forschungsbereich?

4. Welche Defizite methodischer und methodologischer Art im Bereich der Transformationsforschung stehen für Sie im Vordergrund?

5. Wie beurteilen Sie die Forschungspotentiale, die in diesem Bereich in Osteuropa bestehen?

6. Bitte umreißen Sie grob ein Forschungsdesign der Transformationsforschung, das Ihrer Meinung nach der gegenwärtigen Situation adäquat wäre! 